American Journal of Pharmacology and Toxicology 1 (1): 17-20, 2006

ISSN 1557-4962

(c) 2006 Science Publications

\title{
Hepatoprotective Activity of Aqueous Ethanolic Extract of Chamomile capitula in Paracetamol Intoxicated Albino Rats
}

\author{
${ }^{1}$ Ajay Kumar Gupta and ${ }^{2}$ Neelam Misra \\ ${ }^{1}$ Institute of Pharmacy, Bundelkhand University, Jhansi (U.P.)- 284128, India \\ ${ }^{2}$ Department of Biochemistry, Bundelkhand University, Jhansi (U.P.)- 284128, India
}

\begin{abstract}
Hepatoprotective activity of aqueous ethanolic extract of Chamomile recutita capitula against paracetamol induced hepatic damage in albino rats was observed. In the present study the effect of aqueous ethanolic extract of Chamomile recutita capitula on blood and liver glutathione, $\mathrm{Na}^{+} \mathrm{K}^{+}$ATPase activity, serum marker enzymes, serum bilirubin, glycogen and thiobarbutiric acid reactive substances against paracetamol induced damage in rats have been studied to find out the possible mechanism of hepatoprotection. It was observed that extract of chamomile has reversal effects on the levels of above-mentioned parameters in paracetamol hepatotoxicity. The extract of capitula of chamomile functions as a hepatoprotective agent and this hepatoprotective activity of chamomile may be due normalization of impaired membrane function activity.
\end{abstract}

Key words: Chamomile recutita, glutathione, hepatoprotection, lipid peroxidation, $\mathrm{Na}^{+} \mathrm{K}^{+}-\mathrm{ATPase}$, paracetamol, thiobarbutiric acid reactive substances, serum marker enzymes

\section{INTRODUCTION}

Paracetamol hepatotoxicity is caused by the reaction metabolite $\mathrm{N}$-acetyl-p-benzo quinoneimine (NAPQI), which causes oxidative stress and glutathione (GSH) depletion. It is a well-known antipyretic and analgesic agent, which produces hepatic necrosis at higher doses ${ }^{[1]}$. Paracetamol toxicity is due to the formation of toxic metabolites when a part of its metabolized by cytochrome P-450. Introduction of cytochrome $^{[2]}$ or depletion of hepatic glutathione is a prerequisite for paracetamol-induced hepatotoxicity ${ }^{[3,4]}$.

Liver is the vital organ of metabolism and excretion. About 20,000 deaths found every year due to liver disorders. Hepatocellular carcinoma is one of the ten most common tumors in the world with over 2,50,000 new cases each year.

In India, about 40 polyherbal commercial formulations reputed to have hepatoprotective action are being used. It has been reported that 160 phytoconstituents from 101 plants have hepatoprotective activity $^{[5]}$. Liver protective herbal drugs contain a variety of chemical constituents like phenols, coumarins, lignans, essential oil, monoterpenes, carotinoids, glycosides, flavanoids, organic acids, lipids, alkaloids and xanthines. Plant extracts of many crude drugs are also used for the treatment of liver disorders. Extracts of different plants of about 25 plants have been reported to cure liver disorders ${ }^{[6]}$.

In spite of tremendous strides in modern medicine, there are hardly any drugs that stimulate liver function, offer protection to the liver from damage or help regeneration of hepatic cell ${ }^{[7]}$. There are however, members of drugs employed in traditional system of medicine for liver affections ${ }^{[8]}$. Many formulations containing herbal extracts are sold in the Indian market for liver disorders. But management of liver disorders by a simple and precise herbal drug is still an intriguing problem. Several Indian medicinal plants have been extensively used in the Indian traditional system of medicine for the management of liver disorder. Some of these plants have already been reported to posses strong antioxidant activity ${ }^{[9-11]}$.

Chamomile recutita (CV Prashant) L. Rousch, (family Asteraceae), popularly known as Chamomile is a reputed medicinal and aromatic plant used in both traditional and modern system of medicine. It is an ingredient of several traditional, Unani and Homeopathy medicinal preparations ${ }^{[12,13]}$. The capitula of chamomile contain natural oil, known as 'blue oil' (essential oil). The essential oil of chamomile has antiinflammatory and softening effect and is useful in the treatment of gastric colic enteralagia, gastritis, bloating, inflammation and respiratory tract. The main active components of the essential oil are $\alpha$-bisabolol and, chamazulene and oxides of the $\alpha$-bisabolol. The drug is prescribed in constitutional debility, flatulence, colic, hysteria and intermittent fevers. The air-dried flowers on steam distillation yield deep blue oil (essential oil).

But still no scientific and methodical investigation has so far been reported in literature regarding its action on liver. Therefore, the present investigation has been designed to study the possible mechanism of aqueous ethanolic extract of Chamomile recutita on the

Corresponding Author: $\quad$ Dr. Neelam Misra, Amity Institute of Biotechnology, Amity University Uttar Pradesh, Amity Lucknow Campus, Viraj Khand-5, Gomti Nagar, Lucknow-226010, Fax: 91-0522-2721934 
biochemical parameter against paracetamol induced hepatic damage in albino rats.

\section{MATERIALS AND METHODS}

Collection of plant material: Fresh natural mature capitula of Chamomile recutita were collected from the garden field of Bundelkhand University and dried in a shade.

Extraction of plant material: Shade-dried powder (1 $\mathrm{kg}$ of capitula of Chamomile recutita) was extracted by percolation at r.t. with $70 \%$ ETOH. Aqueous ethanolic extract of capitula was concentrated under reduced pressure and dried in a vacuum desiccator $\left(50^{\circ} \mathrm{C}\right)$. The residue $(30.9 \mathrm{gm})$ was dissolved in $70 \%$ ETOH and filtered.

Animals: Albino rats of either sex (100-150 gm) were maintained under control conditions of light and temperature $\left(25^{\circ} \mathrm{C}+1^{\circ} \mathrm{C}\right)$ in animal house of Institute of Pharmacy, Bundelkhand University, Jhansi. Food pellets (DRDE, Gwalior) and tap water were provided ad labium. For experimental, animals were kept fasting overnight but were allowed free access to water.

Paracetamol toxicity: The ethanolic extract of capitula, paracetamol, saline were given with the help of feeding cannels. Three groups (Group I, Group II and III) of rats, six rats in each group were taken. The capitula extract at a fixed dose (400 $\mathrm{mg} \mathrm{kg}^{-1}$, P.O.) that was daily fed for seven days to one group (Group III) of rats and paracetamol (200 mg kg-1 P.O.) was administered on $5^{\text {th }}$ day after $5^{\text {th }}$ administration of the extract. The paracetamol treated group (Group II) received normal saline in place of capitula extract. After $48 \mathrm{~h}$ of paracetamol feeding rats were sacrificed by cervical dislocation for estimation of blood glutathione, reduced liver glutathione, liver $\mathrm{Na}^{+} \mathrm{K}^{+}$ATPase activity, serum marker enzymes, serum bilirubin and liver thiobarbutiric acid reactive substances using standard methods.

Assay of liver glutathione and blood glutathione: Blood was collected, allowed to clot and serum separated. Liver was dissected out and used for biochemical studies. Freshly collected livers were washed with $0.9 \% \mathrm{NaCl}$, weighed and homogenates were made in a ratio of $1 \mathrm{~g}$ of wet tissue to $9 \mathrm{ml}$ of $1.25 \% \mathrm{KCl}$ by using motor driven Teflon-pestle. Reduced glutathione (GSH) was estimated using DTNB $^{[14]}$. The blood glutathione was estimated by the method of Beutler ${ }^{[15]}$. The absorbance was read at 412 $\mathrm{nm}$.

Liver $\mathrm{Na}^{+} \mathrm{K}^{+}$-ATPase activity: To measure the liver $\mathrm{Na}^{+} \mathrm{K}^{+}$-ATPase activity the liver was dissected out quickly, rinsed with cold phosphate buffer, liver plasma membranes were isolated and subjected for the estimation of $\mathrm{Na}^{+} \mathrm{K}^{+}$-ATPase activity ${ }^{[16]}$.

Thiobarbutiric acid reactive substances (TBARS): The concentration of TBARS was measured in liver using the method of Ohkawa et al. ${ }^{[17]}$. The concentration of TBARS was expressed as " moles of malondialdehyde per mg of protein using 1,1,3,3, -tetraethoxypropane as the standard.

Serum marker enzymes: The serum alanine aminotransferase (ALT), aspartate aminotransferase (AST), alkaline phosphatase (ALP) ${ }^{[18,19]}$, total serum protein (TSP) ${ }^{[20]}$ and bilirubin ${ }^{[21]}$ were measured.

Glycogen $(\mathrm{GLY})^{[22]}$ and protein ${ }^{[20]}$ were estimated in liver homogenate.

Statistical analysis: The data were expressed as mean = S.E.M. and statistically assessed by one-way analysis of variance (ANOVA). The difference between drug treated animals and controls was evaluated by student's t-test.

\section{RESULTS AND DISCUSSION}

The glutathione level in liver homogenate and in blood, liver $\mathrm{Na}^{+} \mathrm{K}^{+}$-ATPase, serum marker enzymes and liver thiobarbutiric acid reactive substances are given in Table 1. The concentration of GSH in animals treated with paracetamol was significantly $(\mathrm{p}<0.001)$ reduced in homogenate of liver and so was the level of glutathione in blood and $\mathrm{Na}^{+} \mathrm{K}^{+}$-ATPase level $(\mathrm{p}<0.001)$ as compared with saline control animals. While thiobarbutiric acid reactive substances of paracetamol treated animals was significantly higher $(\mathrm{p}<0.001)$ than the saline treated control animals. Administration of capitula of Chamomile recutita extract increased the concentration of glutathione in liver $(\mathrm{p}<0.01)$ and glutathione in blood $(\mathrm{p}<0.001)$ and liver $\mathrm{Na}^{+} \mathrm{K}^{+}$-ATPase activity significantly $(\mathrm{p}<0.001)$ when compared to its paracetamol treated control group. On the other hand, the increased level of liver thiobarbutiric acid reactive substances of paracetamol treated animals was significantly $(\mathrm{p}<0.001)$ reduced ingroup of animals receiving both capitula extract and paracetamol.

The abnormal high level $(\mathrm{p}<0.001)$ of serum ALT, AST, ALP and bilirubin observed (Table 1) in paracetamol induced liver toxicity. Treatment with AET of $C$. recutita reduced the enhanced level of serum ALT, AST, ALP and bilirubin. On the other hand, the level of liver glycogen of paracetamol treated animals was significantly $(\mathrm{p}<0.001)$ reduced.

Paracetamol is a common antipyretic agent, which is safe in therapeutic doses but can produce fatal hepatic necrosis in man, rats and mice with toxic doses $^{[23-25]}$. Protection against paracetamol-induced toxicity has been used as a test for potential hepatoprotective activity by several investigations ${ }^{[26-30]}$. 
Am. J. Pharm. \& Toxicol., 1 (1): 17-20, 2006

Table 1: Effect of AET of Capitula of Chamomile recutita on blood and liver glutathione (GSH), liver $\mathrm{Na}^{+} \mathrm{K}^{+}$-ATPase, serum marker enzymes (ALT, AST, ALP) and liver thiobabutiric acid reactive substances (TBARS) in Paracetamol intoxicated albino rats

\begin{tabular}{|c|c|c|c|}
\hline Parameters & Group I & Group II & Group III \\
\hline Blood GSH (mg\%) & $1.59 \pm 0.06^{\mathrm{a}}$ & $0.40 \pm 0.05$ & $1.40 \pm 0.04^{\mathrm{c}}$ \\
\hline Liver GSH ( $\mu$ moles $\mathrm{g}^{-1}$ liver $)$ & $11.01 \pm 0.32^{\mathrm{c}}$ & $6.32 \pm 0.34$ & $10.02 \pm .21^{\mathrm{b}}$ \\
\hline $\mathrm{Na}^{+} \mathrm{K}^{+}$-ATPase $\left(\mathrm{U} \mathrm{mg}^{-1}\right.$ protein $)$ & $7.26 \pm 0.54^{\mathrm{a}}$ & $6.21 \pm 0.19$ & $8.06 \pm 0.26^{\mathrm{c}}$ \\
\hline $\begin{array}{l}\left.\text { TBARS ( } \mathrm{n} \mathrm{mol} \text { of MDA } \mathrm{g}^{-1} \text { of wet tissue } \mathrm{h}^{-1}\right) \\
\text { ALT }\left(\mathrm{U} \mathrm{mg}^{-1} \text { protein) }\right.\end{array}$ & $285.7 \pm 10.3$ & $567.4^{\mathrm{a}} \pm 9.5$ & $282.7^{\mathrm{c}} \pm 7.21$ \\
\hline AST $\left(\mathrm{U} \mathrm{mg}^{-1}\right.$ protein $)$ & $59.2 \pm 1.06^{\mathrm{c}}$ & $239.4 \pm 10.9$ & $41.61 \pm 1.89^{\mathrm{c}}$ \\
\hline ALP (KA unit) & $69.4 \pm 2.01^{\mathrm{a}}$ & $172.8 \pm 18.1$ & $44.5 \pm 1.01^{\mathrm{b}}$ \\
\hline Bilirubin (mg\%) (Total) & $58.9 \pm 7.6^{\mathrm{b}}$ & $97.1 \pm 6.84$ & $54.9 \pm 2.4$ \\
\hline $\mathrm{TSP}\left(\mathrm{mg}\right.$ protein $\mathrm{mL}^{-1}$ serum $)$ & $1.43 \pm 0.12^{\mathrm{a}}$ & $2.89 \pm 0.10$ & $1.33 \pm 0.16^{\mathrm{b}}$ \\
\hline $\begin{array}{l}\text { GLY ( } \mathrm{mg} \mathrm{g}^{-1} \text { wet tissue) } \\
\text { Body wejoht }\end{array}$ & $59.89 \pm 2.6^{\mathrm{a}}$ & $56.12 \pm 2.16$ & $61.5 \pm 1.99^{c}$ \\
\hline $\begin{array}{l}\text { Body weight } \\
\text { Before treatment }(\mathrm{g})\end{array}$ & $32.10 \pm 2.94^{\mathrm{a}}$ & $24.45 \pm 1.10$ & $31.49 \pm 2.54^{\mathrm{c}}$ \\
\hline After treatment $(\mathrm{g})$ & $142 \pm 3^{\mathrm{a}}$ & $143.6 \pm 2$ & $141 \pm 4^{\mathrm{c}}$ \\
\hline Liver weight $(\mathrm{g})$ & $153 \pm 5^{\mathrm{b}}$ & $142.3 \pm 3$ & $156 \pm 7^{\mathrm{b}}$ \\
\hline & $6.89 \pm 0.3$ & $5.78 \pm 0.6$ & $6.45 \pm 0.5^{\mathrm{b}}$ \\
\hline
\end{tabular}

Results are mean of six observations \pm S.E.M.

${ }^{a} \mathrm{p}<0.001$ when compared with normal control (Group I).

${ }^{\mathrm{b}} \mathrm{p}<0.001$ when compared with normal control (Group I).

${ }^{c} \mathrm{p}<0.001$ when compared with paracetamol treated control (Group II).

Liver is the most important and main part of the animal body. It is highly affected primarily by toxic agents and that why the above-mentioned parameters have been found to be of great importance in the assessment of liver damage. From our results, it can be speculated that (i) decreasing effect GSH, blood glutathione, liver $\mathrm{Na}^{+} \mathrm{K}^{+}$-ATPase activity and increasing effect of liver thiobarbutiric acid reactive substance level in rat treated with paracetamol were due to hepatocellular damage and (ii) Capitula extract afforded protection from such paracetamol induced liver damage. Possible mechanism that may be responsible for the protection of paracetamol induced the following capitula extract by if self-act as a free radical scavenger intercepting those radicals involved in paracetamol metabolism by microsomal enzymes. Its ability is to inhibit rat hepatic microsomal membrane lipid peroxidation and to scavenge on radicals, as well as to interact with 1,1- di phenyl-2-picrylhydrazyl radical (DPPH). Thus, by trapping oxygen related free radicals capitula extract could hinder their interaction with polyester fatty acids and would abolish the enhancement of lipids peroxidative processes leading to MDA formation ${ }^{[4,11]}$ Capitula extract pretreatment exhibited a normal effect on the glutathione of the blood and liner cells. The extract significantly increased the hepatic and blood glutathione. Then results suggest that a significantly higher content glutathione in blood and liver would offer the tissue a better protection against an oxidative stress, thus contributing to the abolishment of paracetamol infused hepatotoxicity. (c) The activities of $\mathrm{Na}^{+} \mathrm{K}^{+}$-ATPase are decreased in paracetamol-induced animals; capitula extract prevented this effect of paracetamol. Therefore, capitula extract may be useful agent for the normalization of paracetamol induced impaired membrane function ${ }^{[4]}$.

The abnormal high level of serum ALT, AST, ALP and bilirubin observed in our study (Table 1) are the consequence of paracetamol induced liver dysfunction and denotes the damage to the hepatic cells. Treatment with AET of Chamomile reduced the enhanced level of serum ALT, AST, ALP and bilirubin, which seem to offer the protection and maintain the functional integrity of hepatic cells.

A reduction in total serum protein (TSP) (Table 1) and liver glycogen (GLY) observed in the paracetamol treated rats may be associated with the decrease in the number of hepatocytes which in turn may result into decreased hepatic capacity to synthesize protein and GLY and consequently decrease in the liver weight (Table 1). But, when the AET was given along with paracetamol, the significant increase in TSP and liver GLY was observed indicating the hepatoprotection activity of extract and also accounting for the increase in the liver weight most probably through the hepatic cell regeneration

From our results, it can be concluded that decreased the levels of GSH, blood glutathione, serum marker enzymes, liver $\mathrm{Na}^{+} \mathrm{K}^{+}$-ATPase activity and increased liver thiobarbutiric acid reactive substance level in albino rates treated- paracetamol was due to hepatocellular damage. Extract of capitula of Chamomile recutita afforded protection from such paracetamol induced liver damage. Possible mechanism that may be responsible for the protection of paracetamol induced liver damage by capitula extract include the following- (a) Capitula extract could act as a free radical scavenger intercepting those radicals involved in paracetamol metabolism by microsomal enzymes. (b) A significantly higher content GSH in blood and liver would afford the tissue a better protection against antioxidative stress, thus contributing to the abolishment of paracetamol induced hepatotoxicity. (c) Therefore, capitula extract is a promising hepatoprotective agent. The hepatoprotective action combined with antioxidant activity has a synergistic effect to prevent the process of initiation and progress of hepatocellular damage ${ }^{[4]}$. 


\section{ACKNOWLEDGEMENTS}

Financial assistance of the DBT, New Delhi, is gratefully acknowledged. The authors are thankful to Dr. Aseem Chauhan, Chairman and Director General K.K. Ohari (AVSM Retd.), Amity University, Lucknow Campus, Lucknow for their support and encouragement.

\section{REFERENCES}

1. Boyd, E.H. and G.M. Bereczky, 1966. Liver necrosis from paracetamol. Br. J. Pharmacol., 26: 606-614.

2. Dahlin, D., G. Miwa, A. Lu and S. Nelson, 1984, Nacetyl-p-benzoquinone imine: A cytochrome P-450mediated oxidation product of acetaminophen. Proc. Natl. Acad. Sci., 81: 1327-1331.

3. Moron, M.S., J.W. Depierre and B. Mannervik, 1979, Levels of glutathione, glulathione reductase and glutathione-S-transferase activities in rat lung and liver. Biochim. Biophys. Acta, 582: 67-78.

4. Gupta, A.K., H. Chitme, S.K. Dass and N. Misra, 2006a. Hepatoprotective activity of Rauwolfia serpentina rhizome in paracetamol intoxicated rats. J. Pharmacol. Toxicol., 1: 82-88.

5. Handa, S.S., A. Sharma and K.K. Chakraborti, 1986. Fitoterapia, 57: 307-351.

6. Sharma, S.K., M. Ali and J. Gupta, 2002. Phytochemistry and Pharmacology, 2: 253-270.

7. Chaterjee, T.K., 2000. Medicinal Plants with Hepatoprotective Properties. Herbal Options. Books \& Allied (P) Ltd., Calcutta, pp: 155.

8. Chattopadhyay, R.R., 2003. Possible mechanism of hepatoprotective activity of Azadirachta indica leaf extract: Part II. J. Ethanopharmacol., 89: 217-219.

9. Achuthan, C.R., B.H. Babu and J. Padikkala, 2003. Antioxidant and Hepatoprotective effects of Rosa damascena. Pharmaceut. Biol., 41: 357-361.

10. Aniya, Y., A. Miyagi, Nakandakari, N. Kamiya, N. Imaizumi and T. Ichiba, 2002. Free radical scavenging action of the medicinal herb Limonium wrightii from the Okinawa islands. Phytomedicine, 9: 239-244.

11. Gupta, A.K., H. Chitme, S.K. Dass and N. Misra, 2006b. Antioxidant activity of Chamomile recutita capitula methanolic extracts against $\mathrm{CCl}_{4}$-induced liver injury in rats. J. Pharmacol. Toxicol., 1: 101107.

12. Das, M., G.R. Mallavarapu and S. Kumar, 1998. Chamomile (Chamomilla recutita): Economic botany, biology, chemistry, domestication and cultivation. J. Med. Arom. Plant Sci., 20: 1074-1109.

13. Lawrence, B.M., 1996. Progress in essential oils. Perfume. Flavorist, 21: 52-62.

14. Sedlak, J. and R.H. Lindasy, 1968. Estimation of blood protein bound sulphydryl groups in tissue with Ellman's reagent. Anal. Biochem., 25: 192-197.
15. Beutler, E., O. Duran and B.M. Kelly, 1963. Improved method for the determination of blood glutathione. J. Lab. Clin. Med., 61: 882.

16. Corcoram, G.B., S.J. Chang and D.E. Salazar, 1987. Early inhibition of $\mathrm{Na}^{+} \mathrm{K}^{+}$-ATPase ion pump during acetaminophen induced hepatotoxicity in rats. Biochem. Biophys. Res. Commun., 149: 203-207.

17. Ohkawa, H., N. Onishi and K. Yagi, 1979. Assay of lipid peroxidation in animal tissue by thiobarbituric acid reaction. Anal. Biochem., 95: 351-354.

18. Reitman, S. and S. Frankel, 1957. In vitro determination of tranaminase activity in serum. Am. J. Clin. Pathol., 28: 56.

19. Kind, P.R.N. and E.J. King, 1954. Estimation of plasma phosphatase by determination of hydrolysed phenol with amino antipyrine. J. Clin. Pathol., 7: 322.

20. Bradford, M.M., 1976. A rapid and sensitive method for the quantitation of microgram quantities of protein utilizing the principle of protein-dye binding. Anal. Biochem., 72: 248-254.

21. Jendrassik, L. and P. Grof, 1938. Biochemische Zeitschrift, 297: 81-89.

22. Hassid, W.Z. and S. Abraham, 1957. Chemical Procedures for Analysis Of Polysaccarides. In: Colowick, S.P., Kaplan, N.O. (Eds.), Methods in Enzymology, Academic Press Inc., New York, 3: 34.

23. Mitchell. J.R., D.J. Jollow, W.Z. Potter, J.R. Gillettee and B.N. Brodie, 1973. Acetaminophen-induced hepatic necrosis. I. Role of drug metabolism. J. Pharmacol. Expl. Therap., 187: 185-194.

24. Kuma, S. and D. Rex, 1991. Failure of physicians to recognize acetaminophen hepatotoxicity in chronic alcoholics. Arch. Inter. Med., 151: 1189-1191.

25. Eriksson, L., U. Broome, M. Kahn and M. Lindholm, 1992. Hepatotoxicity due to repeated intake of low doses of paracetamol. J. Inter. Med., 231: 567-570.

26. Ahmed, M.B. and M.R. Khater, 2001. Evaluation of the protective potential of Ambrosia maritime extract on acetaminophen-induced liver damage. J. Ethanopharmacol., 75: 169-174.

27. Asha, V.V., S. Akhila, P.J. Wills and A. Subramoniam, 2004. Further studies on the antihepatotoxic activity of Phyllanthus maderaspatensis Linn. J. Ethanopharmacol., 92: 6770.

28. Kumar, G., S.G. Banu, V.P. Pappa, M. Sundararajan and R.M. Pandian, 2004. Hepatoprotective activity of Trianthema portulacastrum L. against paracetamol and thioacetamide intoxication in albino rats. $\mathrm{J}$. Ethnopharmcol., 92: 37-40.

29. Singh, A. and S.S. Handa, 1995. Hepatoprotective activity of Apium graveolens and Hydrophila auriculata against paracetamol and thioacetamide intoxication in rats. J. Ethnopharmacol., 49: 119-126.

30. Visen, P.K.S., B. Shukla, G.K. Patnaik and B.N. Dhawan, 1993. Andrographolide protects rat hepatocytes against paracetamol-induced damage. J. Ethnopharmacol., 40: 131-136. 